\title{
DOES THE SCHOOL LAST IMMUTABLY OR UNCHANGED? EGALITARIANISM AND ELITISM IN THE APPROACH TO EDUCATION IN THE ERA OF GLOBALISATION, TECHNOPOLISATION, INSTANT CULTURE
}

\begin{abstract}
Przybyła Mariusz, Does the School Last Immutably or Unchanged? Egalitarianism and Elitism in the Approach to Education in the Era of Globalisation, Technopolisation, Instant Culture [Czy szkoła trwa niezmiennie, czy niezmieniona? Egalitaryzm i elitaryzm w podejściu do edukacji w dobie: globalizacji, technopolizacji, kultury instant]. Studia Edukacyjne nr 51, 2018, Poznań 2018, pp. 165-182. Adam Mickiewicz University Press. ISSN 1233-6688. DOI: 10.14746/ se.2018.51.9

Globalisation and new media have completely changed the living environment of modern humanity. Technologies have entered almost all spheres of human existence. Education also could not (should not) remain unchanged. The presence of electronic media in the educational process forces a thinking pedagogue to ask questions, including the following: Who are the digital natives and the digital immigrants?

Is the contemporary school on the verge of a chance that it has not had so far? Is this an opportunity to enrich and develop human cognitive function, using the available technical means, by deliberately influencing the course of a number of human life processes, including our development?
\end{abstract}

Key words: education, globalization, technology, IT, instant culture, student and teacher, b-learning

Unrestricted access to education, equality and freedom with regard to civil and social rights and equal rights for citizens regardless of gender, ethnic origin, and beliefs. This is the shortest definition of the egalitarianism of our times. Times that provoke contemporaries to live in a constant hurry. This hurry used to be metaphorically called an instant culture, because of the need to live in "immediacy". ${ }^{1}$ A peculiar triptych of the modern (consumer-orien-

${ }^{1}$ Z. Melosik, Kultura instant. Paradoksy pop-tożsamości, [in:] Edukacja. Społeczne konstruowanie idei i rzeczywistości, Ed. M. Cylkowska-Nowak, Poznań - Toruń 2000. 
ted) world is made up of fast food, fast sex, fast car, symbols of instant pleasure, instant gratification and shrinking space-time. ${ }^{2}$

The lightning speed of the world of youth also includes virtual, hypertextual teleinformation worlds. When analysing the changes in new technologies over the last few years, it is necessary to stop creating artificial distinctions between the world of mobile telephony, the world of the Internet, the world of computers, etc. Contemporary hybrid "multimedia pocket knives" 3 combine the full availability of information with the interpenetration of different applications, widening the spectrum of telecommunication solutions, interlacing them with each other, in one small device. Smartphones are convergent, personalised, small command centres that give young people today the opportunity to take advantage of this immediacy.

The system of values, which seemed to have lasted for centuries, began to crumble under the pressure of mass culture. This picture is drawn at home, at school and on the street, and above all in the media. The mass media - or as it is more appropriate to call them these days, hypermedia - affecting all spheres of our being, reassess the "common order" that guided previous generations. That system in which (at least on the surface) "'Yes' means yes, (...) ' $\mathrm{No}^{\prime}$, no" 4 was an unshakeable bedrock, providing the foundations for future generations who treated it as a matrix of consciousness and identity (Zbigniew Herbert, 2008). A world without shades of grey? Everything that was beyond it was different, unacceptable or stigmatised. The system of values determined the rhythm of the day, was joined with the clock of life, determining the time of birth and the time of death. As a consequence, one lived and often died for those same values.

Reality 'was slow', and constancy always dominated over change. People were most often born and died in the same world. This does not mean that there was no flow of new values, but it was based on the principle of 'distillation'. The new slowly entered public discourses, recalcitrantly becoming a part of everyday life - it sometimes needed almost a century. ${ }^{5}$

After years of socialist living, where the Orwellian reality peered with the strict eye of "Big Brother" 6 into people's pots, books and prayers, we are now living in a time of a conscious, nationwide (international) fascination with

${ }^{2}$ Z. Melosik, Kultura instant jako czynnik socjalizacji, [in:] Pedagogika. Podręcznik akademicki, tom 2, Eds. Z. Kwieciński, B. Śliwerski, Warszawa 2003.

${ }^{3}$ Multimedia pocket knives - by analogy to the world's best multifunctional, multifunctional pocket knives with many options - Swiss army pocket knives.

${ }^{4}$ Matthew 5:33-37, The Bible in the New World Translation.

${ }^{5}$ M. Gliniecki, L. Maksymowicz, Cywilizacyjne uzasadnienie zmian w pracy nauczycieli na rzecz rzeczywistego rozwoju wychowanków, Koszalin 1999.

${ }^{6}$ Term coined by G. Orwell, 2004. 
"Big Brotherism". The fight against the "blackwhite"7 so far has been replaced by the acceptance of any number of shades of grey. ${ }^{8}$

The turn of the century once again did not disappoint its contemporaries, and even surpassed their wildest expectations. In many cases, it also exceeded the ability to perceive and consume what has changed. The rules of functioning in the real world, which is often more virtual than that of Doom or Quake, have been transformed. ${ }^{9}$ What is more, for an increasing number of people, the virtual world has become a part of the real world. Moreover, it is not (as teachers often think) an imaginary existence going on next to "real school", next to real, analogue life; the virtual world is interwoven with the everyday life of contemporary young people. ${ }^{10}$

The world is saturated with constant change. What is contemporary one moment becomes obsolete the next. Humanity lives in a constant hurry, a determined desire to be up to date, a desire to be well informed. At the same time, they are succumbing to such a strong pressure of modernity, and many people living today function in a permanent future shock (term coined by A. Toffler), often in an unsuccessful attempt to keep up with this change.

For the digital emigrant generation (term coined by M. Prensky), constant change is a form of socialisation, a necessity of constantly tuning themselves. In turn, digital natives jump from one cultural discourse to another and it is something natural and ordinary for them. ${ }^{11}$ Their "world is spinning (out of control?) and fewer and fewer people are worried about it".$^{12}$

Many young people perceive science as a direct coercion, a kind of a tethering to classrooms and school benches - a coercion that, even worse, is a necessary evil for them.

It is not the maths or Polish teacher, but the superstars of the film and the stage become personal models. It is not the content of Bolesław Prus' The Doll or Jan Kochanowski's Threnodies that is the subject of lunchtime conversations for students, but the articles printed in Cosmopolitan and 'survival strategies' from the latest computer game. ${ }^{13}$

7 Ibidem.

8 The article contains excerpts borrowed from an unpublished doctoral dissertation by M. Przybyła, Kształcenie zdalne w szkole wyższej - stan i perspektywy, [Distance education in higher education - conditions and perspectives] https://repozytorium.amu.edu.pl/handle/10593/ 2898; Poznań 2012.

${ }^{9}$ Computer games (so-called shooters) of the FPS type - First-person shooter.

10 M. Przybyła, Kształcenie zdalne w szkole wyższej - stan i perspektywy, 2012 https:/ / repozytorium.amu.edu.pl/handle/10593/2898.

11 Z. Melosik, Kultura instant jako czynnik socjalizacji.

12 Z. Melosik, T. Szkudlarek, Kultura, tożsamość i edukacja-migotanie znaczeń, Kraków 1998.

13 Z. Melosik, Kultura instant jako czynnik socjalizacji; cf. M. Przybyła, S. Polcyn, Educational contexts of contemporary computer education of tomorrow. Since education in family to system aspects of education, Sosnowiec 2014. 
A "global teenager" is clearly different from their predecessor. The perception of reality has changed, because the prisms through which this reality reaches young people have changed. Unrestricted access to the Internet - in the pocket of a potential teenager - means that there are no questions that cannot be answered. Young people are labile and mobile, and this is true both when we talk about lifestyle, approach to the value system, to the "here and now", with regard to communication or education. The linear system of reading, taking notes and watching is a thing of the past. Reading from computer monitors, iPods and mobile phones "is not tiring at all" - an assurance that often comes up in intergenerational conversations. Many of those born earlier say so, but at the same time point out that the printed word will survive everything. Printed books will probably continue to exist and will survive the intrusion of electronic books. It is also certain that decoding images, reading texts, fonts distinguished by type, size and colour changes the way information is received and assimilated. E-books mean hypertextuality and the spatial structure of media messages. What counts is immediacy and speed in action and not rational, thoughtful flipping of subsequent pages. The fascination with another unknown, hyper-reality linked to it would seem that "young people are waiting for coincidences, they are playing with them (...)" ${ }^{14}$ This way of perceiving everyday life makes the virtual world of games, films and the Internet closer, and consequently more real. It is even more realistic than the one that is a morning coercion of young people five days a week.

In the times in which we live, value systems have become more pluralistic than ever before. No one is surprised by people "trying on" a new religious system, picking and choosing morality. If one becomes boring or starts to become a burden, we can easily switch to a new one. This relativism has also become established in schools and universities. The media, with the Internet in the lead, broke through the safeguards that separated young people from information that until recently was widely regarded as undesirable. The global network shook up what until recently was considered unshakeable, often showing the axiological structure of humanity in a warped mirror. ${ }^{15}$ Such notions as traditional values, hierarchy, good taste, compassion or authority (previously understood as constants) began to acquire new, often diametrically different meanings.

In the context of the changes that Baudrillard calls the end of the real world, ${ }^{16}$ it is necessary to think about the image of the alma mater that a student has when they walk through the winding corridors of modernity. Will they be able and willing to recognise (also as their own) academic values and

${ }^{14}$ Z. Melosik, Teoria i praktyka edukacji wielokulturowej, Kraków 2007.

${ }^{15}$ J. Morbitzer, Świat wartości w internecie http://www.tuo.agh.edu.pl/Aksjol_Int_AGH_ JMorbitzer.pdf

16 J. Baudrillard, The Intelligence of Evil: or, The Lucidity Pact, London 2005. 
traditions established by previous generations? ${ }^{17}$ Or maybe their university is not a world of values, maybe their role is no longer crucial for the student. Perhaps we all live in a time when "values are freely adopted and abandoned, because reality is understood in terms of the 'offer' of a supermarket". ${ }^{18}$

\section{Globalisation - empowerment or objectification of students and teachers}

The number of discourses raising the issues of globalisation and globality grows with the spread of these concepts and the entry of these terms into new areas (human interests) of knowledge and science. F. Czech ${ }^{19}$ believes that "the debates and reflections on globalisation have been globalised on an equal footing with the phenomena discussed in them and have been held in an increasing number of countries and academic centres". In turn, J. Rokicki points out that "looking at the world through the optics of an eye armed with the notions of globalisation, multiculturalism and postmodernity, we actually look for globalisation, multiculturalism and postmodernity in it. And we find them".${ }^{20}$ Paleczny, Wiącek, Nobis (2011), writing "about different globalities", emphasizes two aspects, related to the increasing spread of raising the issues of globality and globalisation. The author draws attention to a variety of phenomena understood and described as global, and the different perspectives on how they are approached. It is about the diversity of what is referred to as global, but also about the diversity of globality itself.

The concept of globalisation in the definition sphere seems to be still vague. It is important, in the context of the dynamics of the changes taking place, that we seek answers to questions about the semantic meaning and scope of the concept of globalisation. The starting point for reflection on the broad spectrum of the issue under discussion is the recognition of globalisation as a phenomenon. ${ }^{21}$ Theorists dealing with the problems of globalisation seem to be like "two on their opposing suns - Gods"; 22 however, this theory is about our own, earthly globe. The representatives of one trend claim that globali-

17 E. Potulicka, J. Rutkowiak, Neoliberalne uwikłania edukacji, Kraków 2010.

18 Z. Melosik, T. Szkudlarek, Kultura, tożsamość i edukacja.

19 F. Czech, E pluribus unum. Gloss to article by A. Nobis, Kultura - Historia - Globalizacja, $2012,11$.

${ }^{20}$ J. Rokicki, O realności i złudzeniu "globalizacji”, „wielokulturowości” $i$ "ponowoczesności, [w:] Wzory wielokulturowości we wspótczesnym świecie, Eds. K. Golemo, T. Paleczny, E. Wiącek, Kraków 2006, s. 37.

21 A. Cybal-Michalska, T. Gmerek, Globalizacja - aspekt edukacyjny i socjalizacyjny, [in:] Wychowawcze i społeczno-kulturowe kompetencje wspótczesnych nauczycieli. Wybrane konteksty, Ed. J. Pyżalski, Łódź 2015.

22 Juliusz Słowacki, Beniowski. 
sation is the creation of neoliberals, while the others say that globalisation is a real phenomenon that strongly determines (above all) the world's finances. M. Friedman, the creator of the monetary theory, claims that only an unrestricted, free flow of capital across geopolitical boundaries allows its optimal use. Globalisation understood in this way is the highest form of market economy. ${ }^{23}$ It should be remembered, however, that the phenomenon of globalisation itself does not result only from contemporary global transformations; the origins should also be sought in earlier processes noted (often "between the lines") on the pages of the history of many nations.

The concept of globalisation has been highlighted above all by the actions of strong countries, generating and driving the development of the information society, the internationalisation of trade and the unprecedented acceleration of scientific and technological progress. These three interpenetrating spheres determine both the conscious and institutionalised globalisation process ${ }^{24}$ and its spontaneous acceleration. ${ }^{25}$ In order to better understand the basics of the phenomenon and its genesis, it is necessary to grasp this dichotomy.

Globalisation is seen as a lasting and irreversible trend accompanying the changes in social civilisation. It involves not only the spread of phenomena and processes beyond regional or continental borders, but also the concentration of relationships and interdependencies on a global scale, resulting in the interaction of events of local, national and global significance. ${ }^{26}$

Global processes and phenomena are of interest to representatives of various scientific fields, disciplines and research areas. (...). On top of this diversity of science there is also a variety and heterogeneity of phenomena and processes understood as global. It is also the reason for the different understanding of globalism itself and the reference in its study to other categories, methods and concepts. ${ }^{27}$

Regardless of the approach that we adopt, in relation to the impact of global phenomena on social functioning, the most important seems to be the progressing technologisation and technopolisation of everyday life. Technologisation understood as entering and using modern (and increasingly modern) solutions of teleinformation technologies both in the life of individuals and entire communities. And technopolisation, according to the convention adopted by N. Postman (2004), understood as a state of culture and mind consisting in finding the only sense of existence in technology, which is the source

23 A. Giddens, Trzecia droga, Warszawa 1999.

${ }^{24}$ H.P. Martin, H. Schumann, Pułapka globalizacji. Atak na demokracje i dobrobyt, Wrocław 1999.

${ }^{25}$ M. Golka, Cywilizacja, Europa, globalizacja, Poznań 1999.

${ }^{26}$ A. Ćwikliński, Zmiany w polskiej edukacji w okresie globalizacji, integracji i transformacji systemowej, Poznań 2005.

27 A. Nobis, O różnych globalnościach, Kultura - Historia - Globalizacja, 2011, 10. 
of both sanctions and satisfaction. The triumph of technology over culture, as N. Postman writes, lies in questioning the customs, traditions and truths of the Old World with the existence of substitutional, complementary possibilities, technological solutions.

To prayer, the alternative is penicillin; to family roots, the alternative is mobility; to reading, the alternative is television; to restraint, the alternative is immediate gratification; to sin, the alternative is psychotherapy; to political ideology, the alternative is popular appeal established through scientific polling. There is even an alternative to the painful riddle of death, as Freud called it. The riddle may be postponed through longer life, and then perhaps solved altogether by cryogenics. ${ }^{28}$

The Internet has become a modern temple in which, unlike traditional churches, you can create your own piece of reality (also posthumous), believe in it and become its follower. Stanisław Lem (2006) states, however, that more and more often a visible sign of our times is the blurring of the ordering norm. Even postmodernists, who until recently had been bewitched by the cultural melting pot (Jean Baudrillard, Jean François Lyotard), are inclined to moral-ethical reflections and criticism of culture characterised by electronics. It is no one other than Baudrillard who writes, one could say frightened or disgusted by the vision of tomorrow, "In fact, it is the (virtual) machine which is speaking you, the machine which is thinking you", ${ }^{29}$ the author adds, "we removed the real world", ${ }^{30}$ thus painting a vision of hyper-reality, which the Wachowski sisters, creators of The Matrix, may have drawn from the French thinker.

Electronic media completely changed the environment of contemporary human life, entering almost all spheres of its existence. Education also could not (should not) be changed.

The presence of electronic media in the educational process forces a reflective pedagogue to ask many questions, among which it is worth mentioning the following: Who are digital natives? Is it - to cite some views of American authors - the dullest generation, a young people whom the Internet has deprived of part of the cortex, or, on the contrary, a generation that has a chance to be the best educated generation (...) in history? ${ }^{31}$ Or perhaps (following the technicist trail) it is an opportunity unlike any other before, to enrich and develop human cognitive functions with the use of available technical means, through purposeful influencing the course of a number of processes of human life, including our development. The vision of human cyborgisation... ${ }^{32}$

${ }^{28}$ N. Postman, Technopol. Triumf techniki nad kultura, Warszawa 2004.

${ }^{29} \mathrm{~J}$. Baudrillard, The Intelligence of Evil.

30 Ibidem.

${ }^{31}$ J. Morbitzer, Człowiek - media - edukacja, s. 16, http://www.edunews.pl/images/pdf/ eid_listopad_2010.pdf

${ }^{32}$ M. Klichowski, M. Przybyła, Cyborgization yesterday, today and tomorrow: Selected perspectives and educational contexts, [in:] Lifelong learning for labour market needs, Ed. E. Solarczyk-Ambrozik, Poznań 2016, https://repozytorium.amu.edu.pl/bitstream/10593/17226/1/Cyborgization $\% 20$ yesterday $\% 2 c \% 20$ today $\% 20$ and $\% 20$ tomorrow.pdf. 


\section{Who are the contemporary Student and Teacher?}

These are the first questions that come up when we think about the school of the 21st century. The Polish school functions as if beside the Internet. It is fully aware that the Internet exists but would be happy to lock it in computer rooms and open the door only during computer science and information technology classes. The vast majority of teachers have an e-mail account (it is not yet possible to risk claiming that everyone does; and it is not yet clear from having an account that one is using it), but it is usually the first and last form of contact with the student, using the global network. Meanwhile, students are digital natives, treating virtual worlds as an extension of their functioning in the real world. They are in constant contact with modern technology; it is an integral part of learning, play and social contacts. "I, too, am a 'digital immigrant', says Grzegorz Lorek, a biology teacher from Leszno, because I come from a time before the Internet. And students are 'digital natives'. They are attached to the net, they live through their avatars. And then they leave their avatars behind for a moment and come to school. And what is waiting for them there? I - a teacher, standing by the blackboard, chalk in hand. Because I work in a museum of chalk reality. How can I bring the torch of education to them with chalk in hand?"33 The digital divide between technologically advanced youth and some teachers is a fact. The best computers, interactive whiteboards and wireless networks will not change that. Reducing this gap is only possible if the flow of educational and technological innovation is two-way. As long as digital immigrants try to teach digital natives (to use Pernski's terminology) using old methods, this digital disintegration will last. ${ }^{34}$ Until teachers, educators (at least) try to understand the world of the "young", the world of players, the virtual world (which for them, plays out together with the real world), these two worlds will not be able to communicate. S. Polcyn-Matuszewska writes:

A player is first of all a young person in late childhood or adolescence, who devotes most of their free time to playing computer games, who has problems with the immediate social environment: family, teachers and peer group. ${ }^{35}$

It is not just about talking about the problems of children and young people, about lack of contact and lack of understanding. One has to find this thread, or maybe offer to "play".

${ }_{33}$ A. Pezda, http://wyborcza.pl/szkola20/1,106745,7891037,Koniec_epokikredy.html 2010.

${ }_{34}$ J.D.M. Underwood, Rethinking the Digital Divide: impacts on student-tutor relationships, European Journal of Education, 2007, 42, 2.

35 S. Polcyn-Matuszewska, Konstruktywne konteksty wykorzystania gier komputerowych w edukacji - studium przypadku, 2015, http://knm.uksw.edu.pl/konstruktywne-konteksty-wykorzystania-gier-komputerowych-w-edukacji-studium-przypadku/. 
From time to time, echoes of modernity come from educational portals, slogans sounding as incredible as optimistic, which seem to be encouraging, that something is changing, in the often underinvested and anachronistic school reality.

Computers instead of books and tablets instead of notebooks. The teacher no longer writes with chalk on an ordinary board but uses an interactive board. The school of the future? In Wielkopolska, it is already daily life for almost 10 thousand students in 105 schools. $^{36}$

It is important that the boom for modernity is not only an illusory casing that hides the mechanisms we know from the recent past. Replacing yellowed pages and broken foliograms with modern presentations and animations is only half of the success. Electronic materials can be as yellowed and outdated as their analogue predecessors. The ageing of content, which we have come to call digitised, is a process that progresses even faster than the obsolescence of paper dictionaries and encyclopaedias. Pupils and students quickly find out that materials prepared for classes were created the previous year (or worse, earlier still). It is therefore necessary to constantly update the content, examples, graphic, audio-visual and technological setting.

E-learning platforms, which (seemingly) arouse a lot of controversy, are above all a new carrier, a transmitter of knowledge and information. However, they are often criticised, especially by people who do not know their capabilities and do not understand the idea itself. ${ }^{37}$ Jerzy Cieślik ${ }^{38}$ poses questions that may contribute to reflection on the use of e-learning platforms, but above all, a step towards finding the essence of the problem. Is e-learning (blended learning) a technical, organisational or cultural challenge? The author notes, and it is difficult not to agree with him, that technical issues seem to be the easiest to "tame". Of course, it is impossible to rule out the proliferation of "clickological" problems ${ }^{39}$ linked mainly to the need to create an appropriate housing, an "operating manual", an "electronic textbook" for teachers and students alike. Organisational and financial issues related to the introduction of e-learning (b-learning) in academic teaching may pose more problems.

${ }^{36}$ A. Linke 2012, eSzkoła podbija Wielkopolskę, Portal o nowoczesnej edukacji EduNews.pl, http:// www.edunews.pl/narzedzia-i-projekty/ projekty-edukacyjne/1836-eszkola-podbija-wielkopolske

37 A. Granić, M. Ćukušić, Usability Testing and Expert Inspections Complemented by Educational Evaluation: A Case Study of an e-Learning Platform, Journal of Educational Technology \& Society, 2011.

${ }^{38}$ J. Cieślik, E-learning, blended learning - wyzwania techniczne, organizacyjne czy bardziej kulturowe? E-mentor, 2006, 4(16).

${ }^{39}$ An excerpt from an interview with Adam Pawełczak, one of the precursors and translators of the Moodle platform in Poland, an undoubted enthusiast of remote solutions in education, especially academic education (own material). 
"For example, the elimination of the classical formula of a lecture in this way may be difficult to accept for a significant part of the academic community". ${ }^{40}$ The biggest problem related to the introduction of remote solutions in education is the issue of exchanging experiences and sharing knowledge and information. These concepts can be seen as a kind of net culture, which consists in changing the way of thinking about teaching and learning. These transformations concern many issues of functioning itself, e.g. lack of direct contact in teacher-student relations, reluctance to "pin" materials (to e-platforms) that are the intellectual property of the instructors, and fear of these materials being copied by third parties. There is no doubt that these concerns are important, but they are not at the heart of the problem. The vast majority of classes could be supported by content that the teacher would place in a virtual space. Complementary teaching, also called blended learning, assumes that students and teachers use elements of distance learning and do not replace traditional education. As Kaye Thorne ${ }^{41}$ writes in her book on "how to integrate online and traditional learning", the potential of blended learning is almost unlimited and is a naturally evolving process, from traditional forms of learning to individual and targeted development paths using a global network. The best response to most of the emerging accusations, aimed at remote learning, is to show that it is only (and as much as) one of the teaching tools. However, it does not have any ideology or philosophy. ${ }^{42}$

\section{The "copy and paste" - at best "compile" - society}

Another issue related to the use of global web resources (World Wide Web) is plagiarism. There are terrifying visions of a "copy and paste" society, uncritically reproduced content transferred from the Internet directly to bachelor's and master's theses (the former have basically already been completely superseded by final exams), ${ }^{43}$ or using Wikipedia as the main source of indisputable news, on all topics. All this seems to be even more terrible coming from the lips of the teachers, who helplessly spread their hands. Academic lecturers speak about plagues of plagiarism. Contemporary student works

40 Ibidem. 2003.

${ }^{41} \mathrm{~K}$. Thorne, Blended learning: how to integrate online $\mathcal{E}$ traditional learning, pub. Kogan Page

${ }_{42}$ P. Bołtuć, Konstruktywizm w e-edukacji oraz jego krytyka, E-mentor, 2011, 4(41); http:// www.e-mentor.edu.pl/artykul/index/numer/41/id/863.

${ }^{43}$ On the one hand, a lot is said about students' lack of writing skills, expressing thoughts, building logical statements. On the other hand, in the era of competition between higher education institutions intensified by demographic decline, bachelor's degrees are more and more often no longer "crowned" with the achievement of a written paper, or this paper can hardly be called even a "clasp" that encloses an important period. 
are mostly created in electronic form, which is hardly surprising. On the other hand, it is important to be aware that thanks to "autocorrect", spelling issues are thus going to be relegated to the background. Another problem is placing whole paragraphs in student works (often) using the " $\mathrm{Ctrl}+\mathrm{C}, \mathrm{Ctrl}+\mathrm{V}^{\text {" }}$ method. This has become so common that it is (one can assume) completely natural. This is an efficient method that takes little time, a few minutes at most. Internet is a full palette of study guides and crib sheets. ${ }^{44}$ Thanks to them the student (but also the teacher) will find works on any topic. Special websites offer downloading, buying and selling ready-made guides, and they function much more efficiently than the exchange of scientific information..$^{45}$ B. Śliwerski (Sesja plagiatowa, 8 January 2010) writes on his blog: "A plague! With every semester, not even every year anymore, it gets worse and worse. Students probably feel impunity, or the process of ethical degradation has already gone so far that they don't have the slightest sense of decency." Perhaps the student's "taking a shortcut" results from the usual laziness intensified by the tempting offer of these websites. Perhaps it is related to the fact that teachers and lecturers look the other way.

Nevertheless, perhaps the question should be asked: who prepares young people to skilfully use the resources of the global network? Who and when talks about the ethical and legal aspects of using the Internet? Finally, who and how teaches how to use Google tools, Wikipedia, YouTube, Facebook, Instagram, Snapchat, Twitter, who and when teaches prudent use of online banking, online shopping, auction services, etc.? Contemporary Polish school (at all levels) seems to be deaf to these cries. The Internet is still not used in education in our country in a sufficient and correct way, although social and economic needs are very much targeted at these processes. ${ }^{46}$ This does not result from the lack of pedagogical theories or lack of ideas for practical solutions, because from time to time one can read about "innovative" (ongoing) projects supported by the Internet. It is also not the result of the lack of motivation and needs of students who feel good and at ease in this world. The reason seems to be the lesson model, based on the dominance of the teacher, who prefers to give their students "pills" with predefined information (available in textbooks) to "swallow" - memorise. Additional arguments in favour of not being able to prepare young people for the prudent use of electronic applications are to be a large number of student groups, ${ }^{47}$ a lack of open access

${ }^{44}$ http:/ / www.sciaga.pl/ (Sciaga.pl has more than 385 thousand likes on Facebook (access 27.03.2018), in the last 6 years the number of "likes" increased by $150 \%$.

45 S. Kawczyński, Problem plagiatowania w szkolnictwie wyższym. Charakterystyka elektronicznego systemu antyplagiatowego, e-Mentor, 2007, 2(19).

${ }_{46} \mathrm{Z}$. Osiński, Bariery wykorzystania Internetu w polskiej edukacji, Portal innowacyjnego transferu wiedzy w nauce, 2011.

47 Due to the demographic decline, the economic aspect becomes crucial, we close schools so that they are profitable, and we move students to other schools, so that classes are more nu- 
to the Internet in schools and universities (we explain it with technical and financial problems, although it is well known that technologies are increasingly growing cheaper and are intuitively easy to use, even for digital immigrants), a low level of digital literacy of teachers (this argument is unfortunately the biggest and real ailment of Polish education). Polish teachers' fear of the Internet becomes an excuse for accepting 19th-century models of education. The last thread is the level of content and compatibility with global and European standards of web applications developed by institutions, offices and organisations dealing with education. ${ }^{48}$

A practical example of media pedagogy is media education, which aims to prepare people for life in a media world, in particular for the conscious, reflective and critical reception of media messages and the use of the media as tools for communicating, intellectual development and describing the world, including the production of media messages. This is important, mainly in relation to the Internet, where the user - by placing information on the global network - becomes a kind of journalist with a global audience. ${ }^{49}$ Perhaps contemporary "teaching" of media pedagogy should be limited to the conscious prosuming of the media - their creation, promotion and consumption. The school should stop teaching the use of devices and applications, children move freely and naturally in the world of new media, but often they do not know (they do not have) boundaries, do not recognise traps, problems "through the looking glass".

It is impossible not to agree with A. Bard and J. Söderqvist (2006), who claim that everything is changing, and that humanity is forced to look at itself and the world in which we live in a new way - adequate to the situation, because "education ceases to be something given once and for all and must be constantly updated. Every new task is a completely new situation, which usually requires up-to-date knowledge". It should also be noted, after A. Keen (2007), although his view may seem too controversial, that "Cutting and pasting, of course, is child's play on the Web 2.0, enabling a younger generation of intellectual kleptomaniacs, who think their ability to cut and paste a well-phrased through or opinion makes it their own", and the digitisation of almost everything gives (often silent) permission for the functioning of a generation of digital compilers..$^{50}$

merous, regardless of individual needs, of individual development, we use methods from the Industrial Revolution.

${ }^{48}$ Z. Osiński, Bariery wykorzystania Internetu.

${ }^{49}$ J. Morbitzer, Jan Pawet II wobec mediów, Wychowawca - miesięcznik nauczycieli i wychowawców katolickich, 2008, 12.

${ }_{50}$ M. Przybyła, T. Przybyła, Uzależnienia od nowych mediów - czy wymagaja innego podejścia w szkole? [in:] Wychowawcze i społeczno-kulturowe kompetencje wspótczesnych nauczycieli. Wybrane konteksty, Ed. J. Pyżalski, Łódź 2015. 


\section{Teacher vs. student ${ }^{51}$}

"Man learns all his life,

except for school years." ${ }^{\circ 2}$

According to UNESCO representatives, a new vision for higher education needs to be clarified. It is the responsibility of universities to show the challenges of the modern world and to adapt teaching to the progress made in social, cultural, economic and technological life..$^{53}$ One might get the impression that schools are not ready to prepare future generations to enter a completely different labour market than ten or twenty years ago. The current acceleration of civilisation creates a new image of society, an information society, which needs a new school, adapted to the needs and possibilities. "The current solutions have often been worked out by the requirements of industrial civilisation. A school built for the needs of an industrial society cannot fulfil the mission expected by an information society". ${ }^{54}$ A school

patterned after the model appropriate for an industrial society - offering universal education, which emerged with mass production, geared towards a mass audience from the mass media age - no longer fulfils its fundamental function - preparation for life and work, functioning in the society of the future..$^{55}$

"Contemporary schools are under the heavy influence, or even dictatorship, of the Internet", accuses J. Morbitzer, who is at the same time a fervent advocate and enthusiast of the use of new technologies in education.

What is interesting, it is not only the students who succumb to it, but also teachers. (...) For many years, from the appearance of computers and a little later the Internet, education has constantly adapted to the world of technology. And yet the essence of the destructive power of technology lies in monopolising the mental space, in imposing technical thinking on humanity! It is therefore necessary to reverse this relationship: it is not the Internet that should shape the face of the school, it is the school's duty to

51 "vs" or "vs." or "versus" - means no more or less than an opposition. The phrase borrowed from the judiciary and sport has recently become another language skeleton key. We place two heroes in opposition to each other, e.g. in computer games, in virtual, sometimes incoherent worlds, e.g. Aliens vs. Predator. Is this versus "standing" between contemporary Teachers and Students; what positions in this "game" are occupied by both entities of the "match" and on which "level" are they?

52 G. Laub (aphorism); Polish-Czech columnist, journalist, satirist and aphorist.

53 K. Denek, Dydaktyka akademicka i jej efekty, Poznań 2011.

54 B. Śliwerski, Czy program polskiej szkoty odpowiada wymogom nowoczesnego świata? Przegląd, 2009, 35; http://www.przeglad-tygodnik.pl/pl/artykul/czy-program-polskiej-szkoly-odpowiada-wymogom-nowoczesnego-swiata.

55 W. Kołodziejczyk, M. Polak, Jak będzie zmieniać się edukacja. Wyzwania dla polskiej szkoty, referaty z sesji naukowej, Ed. J. Morbitzer, Człowiek - Media - Edukacja, 2011. 
indicate the objectives and rational areas and optimal methods of using this undoubtedly very useful medium. ${ }^{56}$

However, in order for this to happen as postulated by Morbitzer, a higher education institution would have to take a deliberate approach to teaching competences, including those related to the balanced, skilful but realistic use of modern technologies in education. A contemporary student builds their social relations also (and often especially) through the Internet.

Perhaps some of the worries and fears that accompanied people at the turn of the century, one hundred and two hundred years ago, are very similar to those of our contemporaries, and the poet's words, referring to people at the end of the 19th century, seem to sound very universal:

So what is left? In all the faiths of yore
we find no comfort. Things for us are clear.
What is your shield against the evil's spear,
man of the fin-de-siecle?... He spoke no more. ${ }^{57}$

It should be remembered, however, that the class-and-lesson system filled with the sounds of a bell calling for a break, and after a few minutes for the next class, fits perfectly into the atmosphere of the 19th century industrial existence. Does the image of a modern school, which appears to us to be very Herbertian, correspond to the one which is supposed to focus above all on the development of the individual? Or maybe, as B. Śliwerski says,

you don't have to (...) worry too much about the official records of the programmes, because teachers or even parents may demand that some content be supplemented or even eliminated (...). The situation is therefore not bad, nothing is decreed and there is no anxiety. We have sovereign teachers, which is guaranteed by the Teacher's Charter. You can teach even without a textbook, because nobody is a slave to one version. ${ }^{58}$

However, it is important that the need for change is not just a reflection of a small group of teachers and a handful of parents returning from parent-teacher conferences.

Polish education needs further decentralization in the management and socialization of schools, not just a change in the educational model. What good is the access we have to the latest knowledge in universities or academies in the field of more effective education for children and young people, since it cannot be applied under the class-and-lesson system regime. Teachers, no matter how much they may want to teach

${ }^{56}$ J. Morbitzer, (Ed.), Człowiek - Media - Edukacja. Szkoła w pułapce Internetu, Kraków 2012.

${ }^{57}$ Kazimierz Przerwa-Tetmajer, The End of the 19th Century.

${ }_{58}$ B. Śliwerski, Czy program polskiej szkoły odpowiada wymogom. 
differently, cannot, because the Ministry of Education, by means of regulations, i.e. centrally and 'manually', governs the process of education and upbringing. ${ }^{59}$

The need for a systemic transformation in higher education stems from the needs of society, the rapid processes of globalisation, democratisation and integration (...) and the knowledge society and economy based on it. ${ }^{60}$

It is necessary not only to change the way teachers are educated, but also the educational system in our country. It is a mistake to keep the class-and-lesson system in a situation where education becomes a natural part of our socialisation as a result of globalisation processes and universal access to new communication technologies. ${ }^{61}$

Our students are a generation of digital natives, unfortunately, teachers still persist in ossified structures, educating and preparing them to enter the offline world. "Polish education needs further decentralisation in the management and socialisation of schools, not just a change in the educational model. ${ }^{62}$

What is a contemporary student like, standing at the threshold of choosing a further path of life, the name of which is higher education? This, as Z. Melosik (2012) notes, a "global teenager" - drinking Coca-Cola, going to McDonald's, watching MTV, listening to British or American music. According to the research, large-city middle-class youth, regardless of country and continent, have a similar lifestyle and identity. Pop culture is insensitive to regionalism, customs and costumes, it disregards borders, time zones and climate. Popular culture blurs linguistic and religious determinants. "The 'global teenager' adapts quickly, acclimatises, and finds it very easy to communicate (supported by new technologies, which are an extension of their senses).

This modern teenager is a new generation, called Generation Z. Generation $Z$ are people born between 1990 and 2010 (although after 1996 should be assumed in relation to Poland), living in countries with high market saturation with the latest technology, as well as a rapidly developing economy. From an early age, Generation $Z$ grows up, finds itself and moves in the cyber-world, perfectly distinguishes and values technologies. Generation $Z$ are:

- people who grew up in a digital world where technologies have been and continue to be everpresent;

- socially well-informed people who understand the contemporary challenges facing the world, such as terrorism and climate change, due to the continuous availability of an online sea of information;

${ }^{59}$ Interview with Prof. Bogusław Śliwerski" in: Przegląd, 2009, 35.

${ }^{60}$ K. Denek, Nauka i edukacja w uniwersytecie XXI wieku, vol. I, Poznań 2011.

${ }^{61}$ B. Śliwerski, Musimy wyjść z platońskiej jaskini, Forum Akademickie, 2012.

${ }^{62}$ Ibidem. 
- people in constant contact through various media (especially the Internet), often in contact with other countries and cultures, which is not without influence on their decision-making processes;

- young people ready to undertake many tasks (challenges), using technologically advanced devices, at the same time, appreciating simple, intuitive Internet applications. ${ }^{63}$

The global teenager is very tolerant, and even attracted to otherness and diversity, which they can freely adapt on their own. On the other hand, they are distrustful of the need to engage "fully". They are sceptical and therefore do not like pressure and coercion. ${ }^{64}$

Today's teenagers do not change gradually, as was the case earlier, in previous generational "passages". They simply change. Their style, clothing, way of speaking (slang), their carnality, sexuality change. What happened is a generational abyss, a kind of "peculiarity". New media, and therefore new technologies, devices, applications, etc., have changed reality so fundamentally that there is no longer any possibility of retreat. ${ }^{65}$ The lack of retreat is a problem for the school as an institution, for many teachers, educators, and

what is bad for the teacher, because - as they believe - it is a symptom of superficiality, in a non-linear culture, in an instant culture is, perhaps, a condition of cultural success. If there is an inevitable need (...) to 'jump' from one form of manifestation of an instant culture to another, to live in a culture full of contradictions, a culture that does not give clear answers, in which anything can happen, perhaps the lack of commitment (or, more radically, the lack of a core of identity) is the condition for cultural survival. ${ }^{66}$

The school, while upholding principles, supporting development, being a signpost at the crossroads for young people looking for their way, must (in order not to be accused of anachronism) follow the changes that drive modern societies. It is not a matter of expecting it (the school) to be one step ahead of its pupils - it will not be able to do this, because the changes taking place in students' everyday lives are a result of changes in the global world and new technologies. It is not an easy task, and it will be very difficult to meet it, but it does not mean that pedagogues, educators and teachers can walk alongside student passions, enthusiasm, searches and willingness.

\section{BIBLIOGRAPHY}

Adamczewski P., Z praktyki e-learningu na platformie Moodle, E-mentor, 2008, 4(26).

Bard A., Söderqvist J., Netokracja. Nowa elita władzy i życie po kapitalizmie, Warszawa 2006.

\footnotetext{
${ }^{63}$ Grail Research Analysis 2011.

${ }^{64}$ Cf. Z. Melosik, Kultura instant jako czynnik socjalizacji.

${ }^{65}$ M. Prensky, Digital Natives Digital Immigrants, On the Horizon, 2001, 9, 5.

${ }^{66}$ Z. Melosik, Kultura instant jako czynnik socjalizacji.
} 
Baudrillard J., The Intelligence of Evil: or, The Lucidity Pact, Bloomsbury, London 2005.

Bołtuć P., Konstruktywizm w e-edukacji oraz jego krytyka, E-mentor, 2011, 4(41); http:// www.e-mentor.edu.pl/artykul/index/numer/41/id/863.

Cieślik J., E-learning, blended learning - wyzwania techniczne, organizacyjne czy bardziej kulturowe? E-mentor, 2006, 4(16).

Cybal-Michalska A., Gmerek T., Globalizacja - aspekt edukacyjny i socjalizacyjny, [in:] Wychowawcze i społeczno-kulturowe kompetencje wspótczesnych nauczycieli. Wybrane konteksty, Ed. J. Pyżalski, Łódź 2015.

Czech F., E pluribus unum. Gloss to article by A. Nobis, Kultura - Historia - Globalizacja, 2012, 11 .

Ćwikliński A., Zmiany w polskiej edukacji w okresie globalizacji, integracji i transformacji systemowej, Poznań 2005.

Denek K., Dydaktyka akademicka i jej efekty, Poznań 2011.

Denek K., Nauka i edukacja w uniwersytecie XXI wieku, vol. I, Poznań 2011.

Giddens A., Trzecia droga, Warszawa 1999.

Gliniecki M., Maksymowicz L., Cywilizacyjne uzasadnienie zmian w pracy nauczycieli na rzecz rzeczywistego rozwoju wychowanków, Koszalin 1999.

Golka M., Cywilizacja, Europa, globalizacja, Poznań 1999.

Granić A., Cukušić M., Usability Testing and Expert Inspections Complemented by Educational Evaluation: A Case Study of an e-Learning Platform, Journal of Educational Technology \& Society, 2011.

Herbert Z., Kotatka.

http://www.edunews.pl/images/pdf/eid_listopad_2010.pdf

http://www.grailresearch.com/pdf/ContenPodsPdf/Consumers_of_Tomorrow_Insights_and_Observations_About_Generation_Z.pdf

Kawczyński S., Problem plagiatowania w szkolnictwie wyższym. Charakterystyka elektronicznego systemu antyplagiatowego, e-Mentor, 2007, 2(19).

Keen A., Kult amatora. Jak Internet niszczy kulturę, Warszawa 2007.

Klichowski M., Przybyła M., Cyborgization yesterday, today and tomorrow: Selected perspectives and educational contexts, [in:] Lifelong learning for labour market needs, Ed. E. Solarczyk-Ambrozik, Poznań 2016, https://repozytorium.amu.edu.pl/bitstream/10593/17226/1/ Cyborgization\%20yesterday\%2c\%20today\%20and\%20tomorrow.pdf

Kołodziejczyk W., Polak M., Jak będzie zmieniać się edukacja. Wyzwania dla polskiej szkoty, referaty z sesji naukowej, Ed. J. Morbitzer, Człowiek - Media - Edukacja, 2011.

Laub G. (aphorism).

Lem S., Pan Cogito przed monitorem, Polityka.pl kultura, 2006 http:/ / www.polityka.pl/kultura/ludzie/175231,1,lem-stanislaw.read.

Linke A., eSzkoła podbija Wielkopolskę, Portal o nowoczesnej edukacji EduNews.pl, http:/ / www.edunews.pl/narzedzia-i-projekty/projekty-edukacyjne/1836-eszkola-podbija-wielkopolske.

Martin H.P., Schumann H., Pułapka globalizacji. Atak na demokrację i dobrobyt, Wrocław 1999.

Melosik Z., Kultura instant. Paradoksy pop-tożsamości, [in:] Edukacja. Społeczne konstruowanie idei i rzeczywistości, Ed. M. Cylkowska-Nowak, Poznań - Torun 2000.

Melosik Z., Kultura instant jako czynnik socjalizacji, [in:] Pedagogika. Podręcznik akademicki, tom 2, Eds. Z. Kwieciński, B. Śliwerski, Warszawa 2003.

Melosik Z., Teoria i praktyka edukacji wielokulturowej, Kraków 2007.

Melosik Z., Szkudlarek T., Kultura, tożsamość i edukacja - migotanie znaczeń, Kraków 1998.

Morbitzer J., Jan Pawet II wobec mediów, Wychowawca - miesięcznik nauczycieli i wychowawców katolickich, 2008, 12.

Morbitzer J. (Ed.), Człowiek - Media - Edukacja. Szkoła w pułapce Internetu, Kraków 2012. 
Morbitzer J., Świat wartości w internecie, http://www.tuo.agh.edu.pl/Aksjol_Int_AGH_ JMorbitzer.pdf 2004 [dostęp: listopad 2017].

Nobis A., O różnych globalnościach, Kultura - Historia - Globalizacja, 2011, 10.

Orwell G., Rok 1984, "Gazeta”, 2004.

Osiński Z., Bariery wykorzystania Internetu w polskiej edukacji, Portal innowacyjnego transferu wiedzy w nauce, 2011.

Pezda A., http:/ / wyborcza.pl/szkola20/1,106745,7891037,Koniec_epokikredy.html 2010.

Polcyn-Matuszewska S., Konstruktywne konteksty wykorzystania gier komputerowych w edukacji - studium przypadku, 2015, http:/ / knm.uksw.edu.pl/konstruktywne-konteksty-wykorzystania-gier-komputerowych-w-edukacji-studium-przypadku/

Postman N., Technopol. Triumf techniki nad kultura, Warszawa 2004.

Potulicka E., Rutkowiak J., Neoliberalne uwikłania edukacji, Kraków 2010.

Prensky M., Digital Natives Digital Immigrants, On the Horizon, 2001, 9, 5.

Przerwa-Tetmajer K., The End of the 19th Century, transl. J. Zawadzki, Wolne Lektury. https:// wolnelektury.pl/katalog/lektura/ przerwa-tetmajer-the-end-of-the-19th-century.html [accesed: 11.11.2018].

Przybyła M., Kształcenie zdalne w szkole wyższej - stan i perspektywy, 2012 https:/ / repozytorium.amu.edu.pl/handle/10593/2898.

Przybyła M., Polcyn S., Educational contexts of contemporary computer education of tomorrow. Since education in family to system aspects of education, Sosnowiec 2014.

Przybyła M., Przybyła T., Uzależnienia od nowych mediów - czy wymagaja innego podejścia w szkole? [in:] Wychowawcze i społeczno-kulturowe kompetencje wspótczesnych nauczycieli. Wybrane konteksty, Ed. J. Pyżalski, Łódź 2015.

Rokicki J., O realności i złudzeniu "globalizacji", "wielokulturowości" i "ponowoczesności", [in:] Wzory wielokulturowości we wspótczesnym świecie, Eds. K. Golemo, T. Paleczny, E. Wiącek, Wydawnictwo Uniwersytetu Jagiellońskiego, Kraków 2006.

Rozmowa z prof. Bogustawem Śliwerskim, Przegląd, 2009, 35; FA 01/2012; http:/ / forumakademickie.pl/fa/2012/01/musimy-wyjsc-z-platonskiej-jaskini/

Słowacki J., Beniowski.

Śliwerski B., Czy program polskiej szkoty odpowiada wymogom nowoczesnego świata? Przegląd, 2009, 35; http://www.przeglad-tygodnik.pl/pl/artykul/czy-program-polskiej-szkoly-odpowiada-wymogom-nowoczesnego-swiata

Śliwerski B., Sesja plagiatowa, 2010, http://sliwerski-pedagog.blogspot.com/2010/01/ otrzymaem-list-od-mojego-przyjaciela-z.html

Śliwerski B., Musimy wyjść z platońskiej jaskini, Forum Akademickie, 2012.

Thorne K., Blended learning: how to integrate online E traditional learning, pub. Kogan Page 2003.

Underwood J.D.M., Rethinking the Digital Divide: impacts on student-tutor relationships, European Journal of Education, 2007, 42, 2. 